Barbara Ksit

(Swarzędz)

basiaksit@gmail.com

\title{
Działalność publiczna Tadeusza Staniewskiego w Swarzędzu do roku 1918
}

W 1919 r. Tadeusz Staniewski jako pierwszy Polak objął stanowisko burmistrza w podpoznańskim mieście Swarzędz. Funkcję tę pełnił społecznie przez dziewięć miesięcy. Następnie pracował na rzecz miasta jako członek magistratu i przewodniczący Rady Miasta. Ponownie został wybrany burmistrzem w 1929 r. i pełnił tę funkcję nieprzerwanie do 1939 r. Aresztowany po wejściu Niemców do Swarzędza, znalazł się w Forcie VII, skąd wywieziono go do obozu koncentracyjnego w Buchenwaldzie. Tam zmarł 25 sierpnia $1940 \mathrm{r}$.

Pomimo jego licznych zasług dla miasta pamięć o Tadeuszu Staniewskim nie była po 1945 r. w Swarzędzu kultywowana. Dopiero w 1997 r. został patronem jednej z ulic Swarzędza ${ }^{1}$, a w 2010 r. nadano jego imię II Liceum Ogólnokształcącemu. Fakt ten upamiętnia okolicznościowa broszura, zawierająca cztery szkice odnoszące się do biografii i działalności publicznej Tadeusza Staniewskiego ${ }^{2}$. Stał się on też bohaterem kilku artykułów ogłoszonych $\mathrm{w}$ prasie regionalnej ${ }^{3}$. Jego biogram znalazł się w dwóch publikacjach poświęconych powstaniu wielkopolskiemu ${ }^{4}$. Ponadto rozproszone informa-

${ }^{1}$ Uchwała Rady Miejskiej nr XXXIII/238/97 z 18 III 1997, http://bip.swarzedz.pl/fileadmin/BIP/Prawo/Uchwaly/1997/1997_238.pdf (dostęp 16 kwietnia 2018 r.).

2 Tadeusz Staniewski 1873-1940, Swarzędz 2010; wersja online: http://swarzedz.pbp.poznan.pl/files/Staniewski.pdf (dostęp 17 marca 2018 r.).

3 A.M. Szafran, Tadeusz Staniewski (1873-1940), delegat Swarzędza na Polski Sejm Dzielnicowy, „Przegląd Wielkopolski” 2007, nr 2, s. 33-36; M. Szałek, Tadeusz Staniewski: pierwszy burmistrz Swarzędza w odrodzonej Polsce, „Prosto z Ratusza” 2007, nr 10, s. 10-11.

${ }^{4}$ Powstanie Wielkopolskie: mieszkańcy Swarzędza w zwycięskim zrywie niepodległościowym 1918 1919, Swarzędz 2007, s. 44-45; Udział mieszkańców Swarzędza i okolic w Powstaniu Wielkopolskim 1918-1919, Poznań 2015, s. 78-79. 
cje dotyczące Tadeusza Staniewskiego można znaleźć w dwóch monografiach zajmujących się historią Swarzędza ${ }^{5}$.

Wyżej wymienione opracowania omawiają działalność Tadeusza Staniewskiego w Swarzędzu, począwszy od listopada 1918 r., kiedy - jak podaje czasopismo „Postęp" ${ }^{2}$ - w Swarzędzu powstały rady żołnierzy i robotników. Tak Aurelia Szafran-Bartoszek komentuje obecność Tadeusza Staniewskiego w ich zarządzie: „musiał być bardzo znany ze swej działalności i postawy patriotycznej, bo choć był tutaj osobą napływową i nie służył wcześniej w wojsku (za wyjątkiem kilkumiesięcznej służby w tzw. Ersatz-Bataillons w Krotoszynie, od listopada 1916 do lutego 1917), to jednak w listopadzie 1918 r. właśnie z ramienia swarzędzkiej Rady Robotniczej i Żołnierskiej został wybrany Delegatem do Sejmu Dzielnicowego"7.

Niniejszy artykuł ma być próbą poszerzenia wiadomości na temat Tadeusza Staniewskiego we wcześniejszym okresie jego życia. Prześledzenie wydarzeń z lat 1900-1918 pokazuje, jak Tadeusz Staniewski uczył się trudnej umiejętności kompromisu. Zarazem mówi wiele o miejscowym środowisku i unaocznia stan, w jakim społeczeństwo swarzędzkie wkroczyło w niepodległość.

Zasoby Archiwum Państwowego w Poznaniu, szczególnie zespół Akta miasta Swarzędza ${ }^{8}$, przynoszą przede wszystkim informacje na temat działalności Tadeusza Staniewskiego po odzyskaniu niepodległości przez państwo polskie. Natomiast lata 1900-1918, kiedy Staniewski po zdobyciu wykształcenia osiadł w Swarzędzu i stawiał pierwsze kroki w działalności publicznej, $\mathrm{w}$ niewielkim stopniu znalazły swoje odbicie w dokumentacji archiwalnej. Do tego okresu najlepszym źródłem pozostaje prasa wielkopolska. Najwięcej artykułów i ogłoszeń drobnych, w których pojawia się nazwisko Tadeusza Staniewskiego, ukazało się na łamach "Postępu” i „Orędownika”. Jak podaje Wojciech Spaleniak, "Orędownik” był jednym z najpopularniejszych pism w Wielkopolsce9. Podobnie „Postęp" - „pokrewny ideowo »Orędownikowi«,

${ }^{5}$ W. Białek, Swarzędz 1638-1988, Swarzędz 1988; Dzieje Swarzędza: monografia (1638-1988), pod red. S. Nawrockiego, Poznań 1988.

6 „Postęp” 1918, nr 267, s. 3. Oto treść tej notatki: „W Swarzędzu utworzono 13 bm. Radę żołnierzy i robotników. W ostatniej zasiada 8 Polaków, 3 Niemców i 1 żyd; w radzie żołnierzy 4 Polaków i 4 Niemców. Ściślejszy zarząd tworzą: ks. Janicki, Staniewski i Ignacy Mikołajewski. Wszystko w spokoju i porządku".

${ }^{7}$ A. Szafran-Bartoszek, Biografia Tadeusza Staniewskiego, [w:] Tadeusz Staniewski 1873-1940, dz. cyt., s. 11-12.

${ }^{8}$ Archiwum Państwowe Poznań [dalej APP], Zespół: 53/4389: Akta miasta Swarzędz.

${ }^{9}$ Nakład „Orędownika” wzrósł z siedmiuset egzemplarzy w 1871 r. do dziesięciu tys. w 1912 r. W 1886 r. przeszedł na własność Romana Szymańskiego, który uczynił z niego sprawne narzędzie do walki o emancypację polityczną drobnomieszczaństwa. Zasłużył się zwłaszcza w okresie kulturkampfu, gdyż konsekwentnie bronił „wiary i narodowości” (W. Spaleniak, 
lecz bardziej radykalny, bronił interesów drobnego rzemiosła i handlu polskiego"10.

Tadeusz Staniewski urodził się 25 października 1873 r. w Kiełczewie, małej miejscowości pod Kościanem. Ojciec Stanisław (1845-1875?) był z zawodu nauczycielem ${ }^{11}$, matka Stanisława (1851-1938) pochodziła z rodziny Juraszów i była siostrą Antoniego Stanisława Jurasza (1847-1923), wybitnego laryngologa polskiego. Stanisław Staniewski i Antoni Jurasz byli przyjaciółmi ze szkolnej ławy, obydwaj ukończyli Gimnazjum św. Marii Magdaleny i kontynuowali naukę dzięki wsparciu Towarzystwa Naukowej Pomocy i hr. Jana Działyńskiego ${ }^{12}$. Podobną drogę edukacji odbył brat Stanisława, Franciszek Staniewski ${ }^{13}$.

Tadeusz Staniewski miał jedną starszą siostrę - Marię (1871-1940) ${ }^{14}$. Według świadectw rodzinnych, ojciec bardzo wcześnie osierocił rodzinę (w wieku trzydziestu lat), a matka przeniosła się z dziećmi z Kiełczewa do Poznania. Najpierw zamieszkała w domu teściów przy ul. Św. Wojciecha, potem przy ul. Półwiejskiej ${ }^{15}$. Poznańska księga adresowa Adress- und Geschäfts-Handbuch der Stadt Posen z 1879 r. notuje W. Staniewskiego, drukarza, właściciela domu przy ul. Św. Wojciecha 22 (St. Adalbertstrasse). Chodzi tutaj zapewne o Walentego Staniewskiego, zmarłego w 1881 r. ${ }^{16}$, który w 1880 r. obchodził hucznie jubileusz pięćdziesięciolecia pracy w zawodzie drukarskim ${ }^{17}$. Księgi adresowe z 1882 i 1885 r. wykazują jako właściciela domu przy ul. Św.

Encyklopedyczny zarys dziejów prasy wielkopolskiej (1794-1939), [w:] Z dziejów prasy wielkopolskiej XIX-XX wieku, pod red. M. Kosmana, t. 3, Poznań 1997, s. 18-19).

${ }^{10}$ Tamże, s. 19.

${ }^{11}$ W roku szkolnym 1870/1871 pracował w Szkole Realnej w Bydgoszczy, następnie do września 1873 r. w Gimnazjum w Śremie. (Podaję za: Festschrift zur Feier des 50-jährigen Bestehens des Königlichen Realgymnasiums zu Bromberg, Bromberg 1901, s. 34).

12 Zob. A. Białobłocki, Absolwenci Gimnazjum i Liceum Świętej Marii Magdaleny w Poznaniu: 1805-1950, Poznań 1995; D. Gucia, Stypendyści Towarzystwa Naukowej Pomocy im. Karola Marcinkowskiego 1841-1909, Mnichowo-Poznań 2017; Listy Antoniego Jurasza do Jana Działyńskiego, [w:] A. Łączkowski, Antoni Stanistaw Jurasz 1847-1923, Warszawa 1987, s. $24-25$ i in.; Listy Stanisława Staniewskiego w zespole: Listy stypendystów do Jana Działyńskiego z lat 1869-1872 w zbiorach Biblioteki Kórnickiej sygn. BK 07359, BK 07360.

${ }^{13}$ Pamiętnik Zjazdu Abituryentów Gimnazyum ad st. Mariam Magdalenam z r. 1869, Poznań 1895; [nekrolog w:] „Goniec Wielkopolski” z 19 czerwca 1877 r., s. 4.

1418 lipca 1893 r. wyszła za mąż za Aleksandra Całkosińskiego, jak podaje „Dziennik Poznański" z 21 lipca 1893 r., s. 4.

${ }^{15}$ Tadeusz Staniewski 1873-1940, dz. cyt., s. 10. Natomiast według Kartoteki ewidencji ludności 1870-1931 mieszkała w miejscowości Lipnica, 7 marca 1888 r. zamieszkała w Poznaniu przy ul. Półwiejskiej (Halbdorfstrasse) 5, a 7 października 1898 r. przeniosła się na ul. Półwiejską 33 (APP, Zespół: 53/474 Akta miasta Poznania, Seria: 19.3 Kartoteka ewidencji ludności 1870-1931, Jednostka: 15075, k. 524).

${ }^{16}$ APP, Zespól: Urząd Stanu Cywilnego Poznań 53/1926 Seria 4: Akta zgonów, Jednostka: 97. Zob. też nekrolog: „Orędownik” z 27 stycznia 1881 r., s. 2-3.

17 „Orędownik" z 22 kwietnia 1880 r., s. 4. 
Wojciecha 22 wdowę po Walentym Staniewskim, Marię, z domu Schneeberg, zmarłą w 1885 r. ${ }^{18}$

Matka Tadeusza Staniewskiego, Stanisława Staniewska z domu Jurasz, pojawia się w księgach adresowych Poznania w 1888 r. jako przedstawicielka firmy J.N. Leitgeber przy ul. Półwiejskiej 5 (Halbdorfstrasse). W 1891 r. działalność Stanisławy Staniewskiej zostaje określona jako handel towarami kolonialnymi i tak widoczna jest w księgach adresowych do 1904 r., zawsze przy ul. Półwiejskiej 5. Także polskie wydawnictwo Ksiażka Adresowa Handlu i Przemystu Polskiego w obrębie niemieckiego państwa [...] (Berlin 1896) wymienia „handel towarów korzennych" Stanisławy Staniewskiej ${ }^{19}$.

Tadeusz Staniewski ukończył Gimnazjum Fryderyka Wilhelma w Poznaniu. Został do niego przyjęty w $1888 \mathrm{r} \cdot{ }^{20}$ Szkołę ukończył na Wielkanoc $1895 \mathrm{r} .{ }^{21}$ Według świadectw rodzinnych, być może rozpoczął studia ekonomiczne na jednym z uniwersytetów niemieckich. Przebywał bowiem przez pewien czas u swego wuja Antoniego Jurasza w Heidelbergu. W latach 18961898 odbył praktykę w aptece Zygmunta Grochowskiego ${ }^{22}$ w Miłosławiu, zyskując uprawnienia drogerzysty ${ }^{23}$. Pobyt w Miłosławiu potwierdza Kartoteka ewidencji ludności 1870-193124.

29 grudnia 1898 r. Tadeusz Staniewski zawarł związek małżeński z Franciszką Czajkowską ${ }^{25}$. Po ślubie państwo młodzi osiedli w Swarzędzu - według

${ }^{18}$ APP, Zespół: Urząd Stanu Cywilnego Poznań 53/1926 Seria 4: Akta zgonów, Jednostka: 157. Przez kolejne dziesięć lat $w$ księgach adresowych widnieje spadkobierca Marii Staniewskiej (Marie Staniewski Erben). W 1897 r. parcela przy St. Adalbertstrasse 22 określona jest jako „neubau", 1898 pojawia się nowa numeracja - St. Adalbertstrasse 22/23 „unbebaut”.

${ }^{19}$ Jak podaje Antoni Łączkowski, sklep przy ul. Półwiejskiej miał być ślubnym wianem Stanisławy Staniewskiej. Aby zaopatrzyć córkę z okazji ślubu ze Stanisławem Staniewskim, jej ojciec Wawrzyniec Jurasz (z zawodu nauczyciel) miał sprzedać niewielki rodzinny folwark Krzesinki (A. Łączkowski, dz. cyt., s. 9, 22-23).

${ }^{20}$ APP, Zespół : 53/1284, Jednostka 43: Album des Königl. Friedrich Wilhelm Gymnasium zu Posen, s. 119-120.

${ }^{21}$ APP, Zespół : 53/1284, Jednostka 223: Zensurenbogen der 1894-1895 Abgegangenen.

22 Aptekarz Zygmunt Grochowski to także absolwent Gimnazjum Marii Magdaleny i kolejny Wielkopolanin, który zdobył wykształcenie dzięki wsparciu Towarzystwa Pomocy Naukowej (Wykaz młodzieży wspieranéj w latach od 1 Stycznia 1875 roku do końca Grudnia 1880 przez Towarzystwo Pomocy Naukowej [...], Poznań [1881], s. 9).

${ }^{23}$ Tadeusz Staniewski 1873-1940, dz. cyt., s. 10. Drogista, inaczej: drogerzysta - handlujący materjałami aptecznemi. (Podaję za: Słownik języka polskiego, red. J. Karłowicz, t. 1, Warszawa 1900, s. 560).

${ }^{24}$ Według Kartoteki, Tadeusz Staniewski mieszkał od 7 marca 1888 r. przy ul. Półwiejskiej 5 u swojej matki, od 16 maja 1896r. w Miłosławiu, od 3 lipca 1898 r. ponownie przy ul. Półwiejskiej5, a od 7 października 1898 r. przy Półwiejskiej 33 (APP, Zespół: 53/474 Akta miasta Poznania, Seria: 19.3 Kartoteka ewidencji ludności 1870-1931, Jednostka: 15075, k. 520).

${ }^{25}$ APP, Zespół 53/1926 Urząd Stanu Cywilnego Poznań, Jednostka 356: Księga małżeństw za 1898, poz. 621. 
Kartoteki ewidencji - 30 grudnia 1898 r. ${ }^{26}$ W lutym 1900 r. w Swarzędzu urodził się pierwszy syn Tadeusza Staniewskiego - Bogdan Antoni ${ }^{27}$, który zmarł sześć miesięcy później ${ }^{28}$. Franciszka Staniewska zmarła w 1912 r., dwanaście dni po urodzeniu martwej córki ${ }^{29}$. W następnym roku Tadeusz Staniewski ożenił się ponownie, z Haliną Szulczewską ${ }^{30}$. Według wspomnień wnuczki, Justyny Staniewskiej ${ }^{31}$, Tadeusz Staniewski z pierwszego małżeństwa miał troje dzieci: syna Witolda ${ }^{32}$ i dwie córki: Irenę i Halinę. Druga żona urodziła dwie córki: Ludmiłę i Bożenę, które zmarły w dzieciństwie, oraz dwóch synów: Jarosława Andrzeja i Leszka.

W Swarzędzu Tadeusz Staniewski próbował swoich sił na różnych polach działalności gospodarczej ${ }^{33}$. W pamięci mieszkańców Swarzędza pozostał głównie jako właściciel sklepu drogeryjnego, który mieścił się w kamienicy pod adresem Rynek 1234. Już w 1901 r. tygodnik „Praca” wymienia „Skład towarów kolonialnych i drogeryjnych pani Staniewskiej" w Swarzędzu35. Kupiec Tadeusz Staniewski pojawia się w 1908 r. w Księdze kupiectwa i przemysłu polskiego w Wielkim Księstwie Poznańskiem jako właściciel drogerii ${ }^{36}$. W tym

${ }^{26}$ APP, Zespół: 53/474 Akta miasta Poznania, Seria: 19.3 Kartoteka ewidencji ludności 18701931, Jednostka: 15075, k. 521. Natomiast w styczniu 1899 r. w tygodniku „Praca” ukazały się ogłoszenia o wyłączeniu wspólności majątku i dorobku „kupca pana Tadeusza Staniewskiego i panny Franciszki Czajkowskiej ze Swarzędza” („Praca” 1899, nr 4, s. 91).

27 APP, Zespół 53/1955: Urząd Stanu Cywilnego Swarzędz, Jednostka 101: Księga aktów narodzenia, nr 35.

${ }^{28}$ Tamże, Jednostka 139: Księga aktów zejścia, nr 124.

${ }^{29}$ Tamże, Jednostka 222: Księga aktów zejścia, nr 111, 118.

${ }^{30}$ Rodowody miasta Poznania z dnia 7 lipca 1913, „Postęp” 1913, nr 155, s. 3.

${ }^{31}$ Tadeusz Staniewski 1873-1940, dz. cyt., s. 21.

${ }^{32}$ Witold Staniewski, od 1936 r. sędzia Sądu Powszechnego w Śremie, rozstrzelany na Rynku w Śremie 20 października 1939 r. (Podaję za: Słownik biograficzny Śremu, Śrem 2008, s. 313).

${ }^{33}$ Najstarszym dokumentem $\mathrm{w}$ Aktach miasta Swarzędza potwierdzającym więź Staniewskiego z tym miastem jest odręczna notatka z 3 lutego 1899 r., adresowana do Zarządu Policji w Swarzędzu, o przekazaniu kupcowi Staniewskiemu agencji Towarzystwa Ubezpieczeń na Życie Friedrich Wilhelm Berlin i Towarzystwa Ubezpieczeń od Ognia North-British and Mercantile Berlin (APP, Zespół 53/4389: Akta miasta Swarzędz, Jednostka 219: Nachsuchung und Konzessionen und obernahme von Agenturen).

${ }^{34}$ Teofil Hoffmann w „Głosie Swarzędza” 1934, nr 18, s. 1-2, wspominał: „Około roku 1866 wybudowano w mieście naszem pierwsze dwie kamienice większych rozmiarów i to pp. Schleichertów i Brodowskich. Nieco później wybudowano dom p. Staniewskich. Budynki te stanowiły prawdziwą ozdobę miasta". O powodzeniu drogerii Tadeusza Staniewskiego świadczą liczne ogłoszenia zamieszczane przez niego w prasie wielkopolskiej, w których poszukiwał uczniów i pracowników (np. „Postęp” 1903, nr 107, 109, 111; 1906, nr 140, 142, 191; 1906, nr 140; 1907, nr 11; 1909, nr 255; 1910, nr 239; 1912, nr 105, 130, 133, 134, 1913, nr 87; „Przewodnik Katolicki" 1916, nr 12).

${ }^{35}$ Dr. B., Krótki zarys historyczny wsi i miasta Swarzędz, „Praca” 1901, nr 41, s. 1115. s. 199.

${ }^{36}$ Księga kupiectwa i przemystu polskiego w Wielkim Księstwie Poznańskiem, Poznań 1908, 
samym roku pojawiają się $\mathrm{w}$ prasie ogłoszenia o nabyciu przez Tadeusza Staniewskiego fabryki tabaki ${ }^{37}$. Późniejsze księgi adresowe potwierdzają informacje o zajmowaniu się przez Tadeusza Staniewskiego handlem wyrobami tytoniowymi, a w latach trzydziestych także komunikacją samochodową ${ }^{38}$.

Nieznane są powody, dlaczego Tadeusz Staniewski wybrał Swarzędz na miejsce swego osiedlenia się. Być może rozwój handlu drogeryjnego w Poznaniu ${ }^{39}$ skłonił go do poszukiwania miejsca, gdzie nie będzie musiał zmierzyć się z tak dużą konkurencją. Niewątpliwie wielką zaletą Swarzędza była uruchomiona 1 sierpnia $1887 \mathrm{r}$. linia kolejowa ${ }^{40}$.

Tak popularny wówczas tygodnik „Praca” opisywał w 1901 r. ówczesny Swarzędz: „Dziś liczy Swarzędz 3000 mieszkańców, mianowicie 1800 Polaków, 900 Niemców, 300 żydów. Kościół katolicki nie ma pamiątek i grobowców historycznych [...]. Nadto posiada miasteczko ratusz, zbór ewangelicki, bóżnicę i dwie szkoły, katolicką i ewangelicką. Do pierwszej uczęszcza blizko [!] 500, do drugiej 250-300 dzieci. Lekarzem jest p. dr. Błażejczyk. Właścicielem apteki jest Niemiec. Istnieją tutaj dwa polskie towarzystwa: »Tow. Przemysłowców«, prezesem jest p. A. Roszak oraz »Kółko rolnicze«, do którego przeważnie należą rolnicy z okolicy. Prezesem jest p. Jeske z Łowencina. »Spółka stolarska«, która się zawiązała w roku 1898, nieźle prosperuje. Spółka trudni się przeważnie odstawianiem mebli wyrabianych przez stolarzy swarzędzkich, głównie do Poznania"41.

Wymienione wyżej Towarzystwo Przemysłowców powstało w 1894 r., dziś nazwalibyśmy je towarzystwem przedsiębiorców, gdyż w jego skład wcho-

${ }^{37}$ Np. „Postęp" 1908, nr 182.

38 Skorowidz polskiego przemystu i handlu hurtownego Józefa Ziemkowskiego z 1912 r. wymienia nazwisko Tadeusza Staniewskiego w działach Cygar fabryka i handel i Papierosów fabryka $i$ handel (s. 43, 47). W 1923 r. o fabryce tabaki Tadeusza Staniewskiego mówi publikacja Przemyst Wielkopolski Leona Karola Fiedlera (s. 97). Ksiegga adresowa przemystu, handlu i rzemiosta zachodniej Polski z 1925 r. informuje o istnieniu drogerii Tadeusza Staniewskiego w Swarzędzu, i podaje adres: Rynek 12 (s. 386). Informację o drogerii Tadeusza Staniewskiego powtarzają Księga adresowa Polski (wraz z w. m. Gdańskiem) dla handlu, rzemiost i rolnictwa 1926/27 (s. 753) i Księga adresowa Polski (wraz z w. m. Gdańskiem) dla handlu, przemystu, rzemiost i rolnictwa 1928 (s. 1461-1462). Ta ostatnia wymienia także nazwisko H. [!] Staniewskiego w dziale: Samochodowa komunikacja. W kolejnym wydaniu Księgi adresowej Polski z 1930 r. znika drogeria, a T. Staniewski pojawia się tylko jako świadczący usługi z zakresu komunikacji samochodowej (s. 1434).

${ }^{39}$ Przełom XIX/XX w. to w Poznaniu czas szybkiego rozwoju handlu drogeryjnego. W 1896 r. były w Poznaniu 23 drogerie (w tym dziesięć polskich), w 1901 r. - 28 (dwanaście polskich), w 1905 r. - 45 (dwadzieścia polskich). (Podaję za: S. Kopeć, Od Barcikowskich i Czepczyńskich do PZZ „Herbapol” S.A. w Poznaniu: wycinek z dziejów przemystu drogeryjno-zielarskiego i farmaceutycznego w Poznaniu w XIX i XX wieku, Poznań 2003, s. 12).

${ }^{40}$ S. Nawrocki, Pod zaborem pruskim, [w:] Dzieje Swarzędza: monografia (1638-1988), dz. cyt., s. 64 .

${ }^{41}$ Dr. B., dz. cyt. 
dzili przede wszystkim: właściciele warsztatów stolarskich, handlarze i przedstawiciele innych rzemiosł. W 1904 r. Towarzystwo Przemysłowców założyło Polskie Koło Śpiewu (w 1912 r. chór przyjął imię Bolesława Dembińskiego). Także w 1904 r. powstało Towarzystwo Gimnastyczne „Sokół”42.

Nie wiadomo, czy po zamieszkaniu w Swarzędzu Tadeusz Staniewski przyłączył się do tych towarzystw, nie zostało dotąd znalezione formalne potwierdzenie jego członkostwa. Na pewno musiał utrzymywać stosunki z członkami Towarzystwa Przemysłowego. Wydaje się, że po osiedleniu się w Swarzędzu Tadeusz Staniewski rychło stał się tam osobą cenioną. Pewną miarą jego popularności może być fakt, że często proszono go na świadka przy uroczystości zaślubin. Baza Systemu Indeksacji Archiwalnej podaje, na postawie akt Urzędu Stanu Cywilnego w Swarzędzu, że tylko w latach 19001903 był dziesięć razy świadkiem ${ }^{43}$.

Po raz pierwszy nazwisko Tadeusza Staniewskiego jako działacza społecznego pojawia się w prasie w 1906 r., kiedy został wiceprezesem Rady Nadzorczej tzw. Banku Ludowego ${ }^{44}$. Był to rodzaj spółki kredytowo-oszczędnościowej, powołanej do istnienia przez swarzędzkiego proboszcza Tomasza Nejczyka, przy współudziale ks. Piotra Wawrzyniaka, 13 grudnia 1906 r. ${ }^{45}$ Jak podaje Stanisław Nawrocki, Bank Ludowy liczył początkowo 51 członków, by osiągnąć z czasem w 1913 r. liczbę $146^{46}$. Ks. Nejczyk w liście do biskupa Likowskiego tak pisał na temat Banku Ludowego: „podług książek bankowych wypłacono z banku przeze mnie założonego, tutejszym stolarzom a przede wszystkiem rzeźnikom i gospodarzom, moim parafianom na - Prima i Sola-weksle 234698,96 mk. Wątpię, czy mianowicie w czasach krytycznych ci moi parafianie byli mogli swoje weksle gdzie indziej zdyskontować" ${ }^{47}$. Nie wiadomo, jak długo Tadeusz Staniewski pełnił funkcję w Radzie Banku. Sprawozdanie Związku Spótek Zarobkowych i Gospodarczych na Poznańskie i Prusy Zachodnie Za Rok 1907 nie wymienia już nazwiska Staniewskiego wśród członków Rady Nadzorczej ${ }^{48}$. Być może tak szybka rezygnacja z tego stanowiska wiązała się z konfliktem, do którego doszło pomiędzy ks. Tomaszem Nejczykiem a członkami Towarzystwa Przemysłowców ${ }^{49}$. Ów spór z cza-

42 S. Nawrocki, Pod zaborem pruskim, dz. cyt., s. 105-107.

${ }^{43}$ http:/ / www.basia.famula.pl (dostęp 23 grudnia 2017 r.).

44 "Postęp" 1906, nr 29.

45 APP, Zespół 53/4389: Akta miasta Swarzędz, jednostka 313: Sprawy dot. Miejskiej Kasy Oszczędności, k. 4, Pismo Banku Ludowego do Magistratu.

${ }^{46}$ S. Nawrocki, Pod zaborem pruskim, dz. cyt., s. 81.

47 Archiwum Archidiecezjalne w Poznaniu [dalej AAP], Zespół: Konsystorz i Kuria Arcybiskupia, Jednostka KA 789: Akta personalne ks. Nejczyka, list z 20 kwietnia 1914 r.

48 Sprawozdanie Zwiazku Spótek Zarobkowych i Gospodarczych na Poznańskie i Prusy Zachodnie Za Rok 1907, Poznań 1908, s. 96.

${ }^{49}$ W AAP (Zespół: Konsystorz i Kuria Arcybiskupia, Jednostka KA 789: Akta personalne ks. Nejczyka) przechowywane są liczne skargi parafian na proboszcza. Najstarsza z nich nosi 
sem stał się znany poza granicami miasta i omawiany w prasie. Autor anonimowej Korespondecyi. Swarzędz. 28 lutego, pod pseudonimem Przemysłowiec, tak napisał w „Postępie”: „Od czasu, jak ksiądz N. nastał do Swarzędza, zapanowało takie rozdwojenie, jakiego parafia nie pamięta. Tow. Robotników służy jako bat na mieszczaństwo i słowa wypowiedziane przez ks. proboszcza: z wami, bracia robotnicy, chcę i będę pracować - najzupełniej zastosowuje z szkodą miejscowego społeczeństwa" ${ }^{50}$. Między innymi bowiem ów Przemysłowiec zarzucił księdzu, że w zarządzie Banku Ludowego wymienił doświadczonych kupców na niewykształconych, ale posłusznych robotników.

Kiedy w 1905 r. do parafii swarzędzkiej przybył ksiądz Tomasz Nejczyk, oznaczało to dla miejscowej społeczności wiele zmian. Z jednej strony, założył on nowe organizacje - jak Katolickie Towarzystwo Robotników Polskich czy Towarzystwo Chóru Kościelnego pod wezwaniem św. Cecylii51. Z drugiej strony, szybko stał się on przedmiotem niechęci części mieszkańców Swarzędza. Z czasem także Tadeusz Staniewski został stroną w parafialnych sporach, zwłaszcza gdy wybrano go członkiem tzw. nadzoru kościelnego ${ }^{52}$.

Warto zwrócić uwagę na Towarzystwo Robotników, które ksiądz proboszcz założył zgodnie z zachętą arcybiskupa Floriana Stablewskiego ${ }^{53}$. Swarzędzkie Towarzystwo już na wiosnę 1906 r. liczyło dwustu członków, jego prezesem był Józef Młyńczak, sekretarzem Walenty Krzyżaniak ${ }^{54}$. Rychło też stało się siłą, pragnącą odgrywać w mieście rolę polityczną. Nazwiska członków Towarzystwa, podobnie jak nazwisko Tadeusza Staniewskiego, poja-

datę 24 czerwca 1907 r., ale z treści wynika, ze jest kolejną z wielu. Pod pismem podpisał się Józef Cabański, rzeźnik, prezes Towarzystwa Przemysłowego i inni członkowie tego Towarzystwa.

${ }^{50}$ Korespondecya. Swarzędz 28 lutego, „Postęp” z 3 marca 1909 r., s. 1-2.

${ }^{51}$ Księża spotecznicy w Wielkopolsce 1894-1919, t. 2 I-O, Gniezno 2007, s. 333-334; A. Bartoszek, Ksiądz Tomasz Nejczyk (1865-1918) - proboszcz swarzędzki, "Zeszyty Swarzędzkie” 2011, t. 3, s. 88103.

52 Nadzór kościelny to instytucja powołana zarządzeniem arcybiskupa Mieczysława Ledóchowskiego z 1871 r., skorygowanym potem ustawą cesarską z 20 czerwca 1875 r. o zarządzie majątków w gminach kościelnych katolickich. W skład dozoru parafii wchodziło kilku prowizorów kościelnych (Kirchenvorsteher), wybieranych przez parafię. Był to urząd honorowy.

${ }^{53}$ Pierwsze takie Towarzystwo zostało założone w Poznaniu w 1892 r. przez ks. Antoniego Stychla i opracowany przez niego statut został uznany za wzorcowy. Czytamy w nim: „Zadaniem Towarzystwa jest: 1 . obrona i szerzenie religijności i dobrych obyczajów w ścisłym związku z kościołem. 2. ogólne oświecenie umysłu i szczegółowe pouczenie członków w sprawach żywotnych stanu robotniczego. 3. popieranie materialnych interesów stanu robotniczego i pomoc wzajemna członków. 4. utrzymywanie koleżeńskich stosunków i wspólna skromna zabawa" (Ustawy katolickiego Towarzystwa Robotników Polskich w Poznaniu. Podaję za: M. Wojciechowska, Materiały do dziejów katolickich towarzystw robotników polskich w Wielkopolsce, „Poznańskie Studia Teologiczne" 1986, t. VI, s. 399-422).

${ }^{54}$ Spis Katolickich Towarzystw Robotników Polskich należących do Związu diecezjalnego archidiecezji gnieźnieńskiej i poznańskiej. Dodatek do: „Robotnik” z 4 marca 1906 r. 
wiają się na łamach prasy wielkopolskiej w kontekście dwóch wydarzeń, które były ważne dla Polaków w Swarzędzu. Chodzi tutaj o wybory do Rady Miejskiej w 1909 r. i sprawę budowy Domu Katolickiego.

W 1909 r. ukazały się w prasie wielkopolskiej liczne ogłoszenia Komitetu Wyborczego w Swarzędzu, podpisane przezjego przewodniczącego Tadeusza Staniewskiego ${ }^{55}$. Zachęcały one mieszkańców do sprawdzenia swojego nazwiska na liście wyborców. Aby móc wziąć udział w wyborach, które miały miejsce w listopadzie 1909 r., obywatel musiał się zapisać na liście wyłożonej w magistracie do 30 lipca. Dlatego Komitet apelował: „Po 30 lipca wszelkie zgłoszenia prawnie nie są ważne, zatem kto nie zaśpi tej ważnej sprawy, ten tylko może na przyszłe wybory się stawić!" 56 .

Tadeusz Staniewski oprócz pracy w Komitecie zgłosił także swoją kandydaturę na radnego. Niestety, nie został wybrany, przepadł w wyborach, podobnie jak inni polscy kandydaci. Mimo zaostrzającego się kursu antypolskiego władz pruskich dotąd udawało się Polakom wprowadzić swojego przedstawiciela do Rady Miejskiej ${ }^{57}$. Natomiast wybory 1909 r. okazały się dla sprawy polskiej kompletną klęską. Przegrana ta odbiła się echem na łamach prasy wielkopolskiej. Gazety odnotowały klęskę polskich kandydatów w Swarzędzu jako powód smutku i wstydu dla wszystkich rodaków. Najbardziej zaciekła polemika rozegrała się na łamach "Postępu”. Padło wiele imiennych oskarżeń i zarzutów, że swarzędzanie swoje egoistyczne ambicje przedkładają nad dobro sprawy narodowej.

30 listopada 1909 r., a więc w tydzień po wyborach, czasopismo „Postęp” zamieściło na swoich łamach obszerną relację anonimowego korespondenta ze Swarzędza, który podpisał się jako Wyborca ${ }^{58}$. Autor rzecz całą rozpoczyna opisem spotkania przedwyborczego, które odbyło się w niedzielę 21 listopada. Wiec „zagaił p. Staniewski, członek komitetu miejscowego, pochwaleniem Pana Boga i wyjaśnił cel wieca i wygłosił pięknie i zrozumiale opracowaną naukę o wyborach". Następnie z działalności Rady dał sprawozdanie dotychczasowy radny Józef Cabański, a potem odczytano nazwiska trzech kandydatów, proponowanych przez komitet w zbliżających się wyborach. Kandydatami tymi byli: Józef Cabański, Tadeusz Staniewski, Maksymilian Mikołajczak. Zdaniem Wyborcy, wszyscy kandydaci zyskali poparcie większości zebranych i uchwała zatwierdzająca ich wybór zapadła legalnie. Natomiast już po zamknięciu obrad miała wybuchnąć awantura. Niektórzy z uczestników żądali przedłużenia obrad, chcieli zgłosić jeszcze

${ }^{55}$ Np. „Postęp” 1909, nr 164, 165, 258, 259, 260, 261, 262, 264.

56 Wybory, „Postęp" 1909, nr 164.

${ }^{57} \mathrm{Na}$ przykład w 1897 r. przewodniczącym Rady był lekarz dr Sylwester Wendland, w 1903 - rzeźnik Józef Cabański. (Podaję za: S. Nawrocki, dz. cyt., s. 75).

${ }^{58}$ Wyborca, W sprawie wyborów swarzędzkich, „Postęp” 1909, nr 273, s. 2. 
inne kandydatury ${ }^{59}$. Następnego dnia, w poniedziałek 22 listopada, przedstawiciele Towarzystwa Robotników udali się do Poznania i przed członkiem Komitetu Prowincjalnego Konstantym Kościńskim złożyli skargę na działalność swarzędzkiego Komitetu Wyborczego. Tego samego dnia wieczorem przybył do Swarzędza Kościński wraz z redaktorem „Dziennika Poznańskiego" Hojnackim. Kościński uznał postanowienia niedzielnego zebrania za legalne, jednak aby poznać zamierzenia drugiej strony, udał się do księdza proboszcza Nejczyka, a potem na posiedzenie zwołane przez Lutomskiego, prezesa Towarzystwa Robotników.

Na zebraniu robotników miano, zdaniem Wyborcy, postawić trzech kandydatów - pp. Cabańskiego, Mikołajewskiego i Schleicherta. Wysłano również posłów do miejscowego Komitetu Wyborczego, ale jego członkowie orzekli, że nie mogą przybyć na nielegalnie zwołane posiedzenie. Niemniej „przyrzeczono uroczyście, jeżeli będą głosować jak na wiecu uchwalono, to po przeprowadzeniu ustępuje dobrowolnie na rzecz robotnika p. Staniewski pod tym warunkiem, że jeden z robotników zasiądzie w radzie".

W gorączkowej atmosferze oczekiwano następnego dnia, gdyż wybory miały odbyć się we wtorek 23 listopada, między godziną drugą a czwartą po południu. Tymczasem we wtorek o godzinie pierwszej Edward Schleichert przysłał swoich posłańców do Tadeusza Staniewskiego, aby ten zrzekł się kandydatury, gdyż w przeciwnym razie robotnicy zbojkotują wybory. „Staniewski dla miłej zgody, choć czuje się skrępowany uchwałą wieca, przystaje pod warunkiem, że p. E. Schl. przyjdzie do zebranego komitetu i uzna swój błąd i niesłuszną walkę przeciw komitetowi, ale E. Schl. każe buńczucznie odpowiedzieć, że do podobnych żądań jest - za stary".

Dalej ów anonimowy sprawozdawca zarzuca przedstawicielom robotników, że w trakcie wyborów, czyli między godziną drugą a czwartą, stali na schodach ratuszowych, zniechęcając rzemieślników do wzięcia udziału w wyborach, wręcz spychali ich ze schodów, a tych, którzy się z nimi zgadzali, zapraszali „do knajpy na słodką". Kiedy po godzinie czwartej policzono głosy, okazało się, że choć Polacy oddali w wyborach większą liczbę głosów niż Niemcy, wszyscy polscy kandydaci przepadli ${ }^{60}$.

59 „Dotąd było jak najspokojniej, po zamknięciu wieca [!] podnosi organista miejscowy p. Zaporowski - że to nieprawnie, to za prędko - powstaje hałas tak, że trudno zrozumieć, o co chodzi. P. G. krzyczy - że na socyalistę [!] będą głosować - p. R. - waląc w podłogę krzesełkiem klnie i wyzywa - p. L. prezes Tow. Rob., który nie jest uprawniony do głosu (nie był na liście) wali pięścią w stół, wołając - ja wam pokażę. P. E. Schleichert rozczerwieniony namiętnie ze złością podnosi pięści ku estradzie, krzyczy coś niezrozumiale".

${ }^{60}$ Z 227 uprawnionych głosów polskich „oddano na p. Cabańskiego 109, na p. Mikołajczaka 106, na p. Staniewskiego 103, a sławetny p. Schleichert otrzymał głosów 5. Z 175 niemieckich głosów otrzymał Niemiec p. Akt 121 głosów, p. O. Liefke, także Niemiec 125, i żyd Fabian 125 głosów". 
Autor wystąpienia w „Postępie” stawia w związku z tym oskarżenia pod adresem konkretnych osób ${ }^{61}$. Zaatakowani przez Wyborcę odpowiedzieli Oświadczeniem, opublikowanym przez „Postęp” tydzień później, we wtorek 7 grudnia 1909 r. ${ }^{62}$ Przedstawiciele Towarzystwa Robotników stwierdzili, że już na kilka tygodni przed wyborami doszli do porozumienia z Komitetem Wyborczym. Ustalono, że przemysłowców w wyborach reprezentować będą Józef Cabański i Tadeusz Staniewski, a robotników - Edward Schleichert. To, że na zebraniu przedwyborczym postawiono kandydaturę Maksymiliana Mikołajewskiego zamiast Edwarda Schleicherta, robotnicy odebrali jako oszustwo. Głosowaniem kierowano w taki sposób, by jak najszybciej zamknąć posiedzenie i protestującym odebrać prawo głosu. Ponadto wybrano krzywdzącą dla robotników formę głosowania przez powstanie z miejsc ${ }^{63}$. Dalej przedstawiciele robotników zapewniają, że zaprosili do Swarzędza przedstawicieli Komitetu z Poznania w intencji pokojowej oraz aby okazać, że robotnicy stoją jak jeden mąż za Edwardem Schleichertem. „Panowie z Poznania od Komitetu centralnego pragnęli obecności miejscowego Komitetu dla nawiązania rokowań pojednawczych na zebraniu i w tym celu wysłaliśmy do nich dwóch posłów z prośbą o przybycie, a rezultat był ten, że członek Komitetu miejscowego p. Staniewski dał naszym posłom taką odprawę: Idźcie do djabła, niechaj ten chłop, wasz ksiądz, na was głosuje!". Te obraźliwe słowa Tadeusza Staniewskiego i butna postawa Komitetu sprawiły, że robotnicy postanowili powstrzymać się od głosowania. Ich zdaniem, to Komitet Wyborczy ponosi winę za klęskę Polaków w wyborach ${ }^{64}$.

Redakcja dziennika „Postęp” zamieściła Oświadczenie Towarzystwa Robotników dla zachowania bezstronności, ale dołączyła komentarz, w którym

61 „Z oddanych polskich głosów kilka głosów przypada na robotników, ale nie jest to wyłącznie wina tych reszty, co nie poszli na wybory, bo ci ludzie nie umieją należycie ocenić podobnych spraw, ale wina jednostek, którzy pod naciskiem ks. prob. Nejczyka do tego parli, ażeby nie dopuszczać zacnych i prawych Polaków, ale im niedogodnych, do pracy społecznej". Dalej następuje lista nazwisk osób związanych z ks. Nejczykiem, jak organista, kościelny i członkowie Towarzystwa Robotników.

${ }^{62}$ Oświadczenie [Towarzystwa Robotników], „Postęp” 1909, nr 279, s. 1-2.

${ }^{63} \mathrm{Na}$ sali zabrakło krzeseł dla wszystkich wyborców. Większość robotników stała przy drzwiach. Ci, którzy akceptowali kandydatów zgłoszonych przez komitet, mieli powstać z miejsc, a siedzieć mieli ci, którzy byli przeciw. „Rozumie się, że cała partya [!] robotników, przeciwna narzuconemu im w miejsce $\mathrm{p}$. E. Schleicherta kandydatowi, nie mogła wnieść swego veto przez niepowstanie $\mathrm{z}$ miejsc, bo już stała, a dla ośmieszenia się nie mogli ci ludzie przecież usiąść na podłogę jak dzieci".

${ }^{64}$ Ponadto w Oświadczeniu podkreślono, że „znienawidzony przez p. Cabańskiego i jego popleczników” ks. Nejczyk „nie brał w akcyi wyborczej żadnego udziału”. 
nazwała robotników „zdrajcami sprawy narodowej”65. „Dziennik” i „Kurier Poznański” zgodnie pytały: „Kto winien?”66.

Ostatecznie, jak doniósł „Orędownik”, Komitet Prowincjonalny Powiatu Poznańskiego Wschodniego uznał postępowanie komitetu pod kierownictwem Tadeusza Staniewskiego za legalne ${ }^{67}$.

W końcu XIX i na początku XX w. w Swarzędzu coraz bujniej rozwijało się życie obywatelskie. Polacy coraz częściej łączyli się w stowarzyszenia. Towarzystwa te rychło odczuły potrzebę miejsca, gdzie mogłyby się spotykać. Stąd zrodziła się idea budowy Domu Katolickiego, która choć zaprzątała umysły swarzędzan przez wiele lat, długo nie mogła wydać owocu. Losy tego przedsięwzięcia wydają się bardzo zawikłane, wpłynęła na nie sytuacja w parafii, trudna zarówno pod względem materialnym, jak i sporów międzyludzkich.

Historię projektu budowy Domu przynosi obszerny tekst $W$ sprawie Domu polsko-katolickiego w Swarzędzu, zamieszczony w „Postępie” z 10 marca 1914 r. ${ }^{68}$ Pod tekstem podpisał się Parafialny Komitet z Tadeuszem Staniewskim jako przewodniczącym. W tym artykule twierdzi się, że już w 1903 r., podczas zebrania Towarzystwa Przemysłowego 1 listopada, lekarz dr Błażejczyk rzucił myśl budowy Domu Katolickiego. 15 listopada 1903 r. powstał Komitet, który energicznie wziął się do pracy i 5 stycznia 1904 r. złożył pewną kwotę na przyszły dom do Banku Przemysłowców w Poznaniu. Przedsięwzięcie straciło impet, gdy Swarzędz opuścili dr Błażejczyk i ks. Sikora. Natomiast ks. Nejczyk krótko po swoim przybyciu powziął niechęć do osób związanych z Towarzystwem "Sokół” oraz Towarzystwem Przemysłowym, i dlatego nie wspierał działalności powołanego przez nich komitetu. Co więcej, powołał drugi komitet, bojkotujący starania pierwszego ${ }^{69}$. Trudno ocenić, na ile

${ }^{65}$ Ponadto redaktor „Postępu” wyraził obawę, że „robotnika zwykłego postawić na radnego miejskiego jest rzecz ryzykowna, bo przede wszystkiem robotnik nie ma czasu chodzić na posiedzenia rady miejskiej i różne inne załatwiać czynności, wynikające z takiego urzędu, gdyżby stracił przynajmniej połowę swego zarobku, bo przecież te urzęda są honorowe".

66 „Dziennik Poznański” 1909, nr 272, s. 3; „Kurier Poznański” 1909, nr 272, s. 3.

${ }^{67}$ Ponadto Komitet Prowincjonalny (prezes Stefan Cegielski, wiceprezes ks. Piotr Wawrzyniak) osądził również, że „Komitet miejscowy nie ponosi odpowiedzialności za wynik niepomyślny [wyborów]. Do zerwania solidarności przyczynili się [...] nie tyle ludzie w sprawach wyborczych niedostatecznie uświadomieni, jak raczej ci, którzy mając ze względu na powołanie swoje sposobność i obowiązek do pouczania drugich i szerzenia zgody, od obowiązku tego się usunęli". (W sprawie wyborów do rady miejskiej w Swarzędzu. "Orędownik” z 24 grudnia 1909 r., s. 3).

${ }^{68}$ W sprawie Domu polsko-katolickiego w Swarzędzu, „Postęp” 1914, nr 56 s. 1.

${ }^{69}$ Natomiast ks. Tomasz Nejczyk w liście do biskupa Edwarda Likowskiego z 28 lutego 1907 r. informuje: „Komitet budowlany Domu Katolickiego utworzyłem dnia 6 listopada 1905 r., w składzie... [tu następuje lista dziewięciu nazwisk, w tym Tadeusza Staniewskiego]. Komitet działał do jesieni 1906 r., czego dowodzi książka składek przełożona na wizytacji 31 stycznia 1907. Tymczasem w listopadzie 1906 p. Cabański z nieznanych przyczyn założył własny ko- 
Tadeusz Staniewski był wówczas zaangażowany w ów spór, niemniej popierał plan budowy ${ }^{70}$.

Aby rozstrzygnąć spór, sprawę oddano pod osąd władzy duchownej. W jej imieniu obu stron wysłuchał 22 kwietnia 1907 r. ks. prodziekan Manicki z Nekli. Na tym spotkaniu dano ks. Nejczykowi następujące warunki do podpisania: „1) że wszystkie nasze polsko-katolickie towarzystwa, obok kościelnych i świeckie, jak Przemysłowcy, Śpiewacy, Sokoli, Rolnicy, Robotnicy itd. będą mogły swe posiedzenia ewentualnie ćwiczenia i zabawy odbywać; 2) że wszystkie nasze polityczne zebrania i wiece, bez przeszkody każdego czasu mogą być urządzane; i wreszcie 3) że nie na gruncie kościelnym i bez najmniejszej subwencyi rządowej będzie budowany przyszły Dom katolicki". W zamian za przyrzeczenie powyższego zapewniono ks. Nejczyka, że pierwszy komitet się rozwiąże, sumy dotąd zebrane ks. Nejczykowi przekaże, a co więcej, dwóch obecnych na zebraniu obywateli zobowiązało się natychmiast ofiarować po tysiąc mk. Ks. Nejczyk tę propozycję odrzucił. Wówczas „komitet przemysłowców" zawiesił swoją działalność do czasu pojednania z ks. Nejczykiem. Natomiast „komitet proboszcza” wciąż istniał, natomiast zdaniem autora artykułu był całkowicie bierny - przez pięć lat nie zwołano ani jednego zebrania. I tak ta pasywna sytuacja trwała do $1913 \mathrm{r}$.

Konflikt w parafii zaostrzył się jesienią 1913 r. Wówczas "Orędownik” w artykule pt. Opłakane stosunki w parafii swarzędzkiej ${ }^{71}$ doniósł, że 22 września odbył się wiec parafialny, który dotyczył zarówno trudnej sytuacji finansowej parafii, jak i spraw religijnych. Tadeusz Staniewski wystąpił na wiecu „W imieniu dozoru kościelnego". Po dyskusji parafianie uchwalili dwie rezolucje do władz kościelnych - pierwszą w sprawach majątkowych ${ }^{72}$, drugą w kwestii stosunków religijnych ${ }^{73}$. Trzecim poruszonym problemem była

mitet z zięciem Stefanem Mikołajewskim i nowymi ludźmi". Dalej wyjaśnia, że w wyniku rozłamu kilka osób wycofało swoje poparcie (AAP, Zespół: Konsystorz i Kuria Arcybiskupia, Jednostka KA 789: Akta personalne ks. Nejczyka, list pt. Pokorna odpowiedź na zarzuty ponowne p. Józefa Cabańskiego i towarzyszy). Ponadto w aktach ks. Nejczyka istnieje dokument datowany na 21 kwietnia 1907 r., w którym członkowie Towarzystwa Robotników i Chóru Kościelnego zakładają „Komitet do wybudowania sali zebrań”. Widnieje pod nim 87 podpisów.

${ }^{70}$ W czasopiśmie „Postęp" 1907, nr 45, widnieje lista ofiarodawców „na budowę Domu Katolickiego". Tadeusz Staniewski ofiarował trzy mk.

${ }^{71}$ Optakane stosunki w parafii swarzędzkiej, "Orędownik” 1913, nr 220, s. 2.

${ }^{72} \mathrm{~W}$ rezolucji parafianie zwracają się do konsystorza, aby zechciał „rzeczywisty stan majątku kościelnego od czasu śmierci śp. ks. dziekana Dambka zbadać, ponieważ dozór nie mając żadnych podkładek książkowych (bo książek nie ma) nie jest w stanie przekonać się, jak rzeczy stoją".

73 „My zgromadzeni parafianie w liczbie przeszło 300 na wiecu [...] zanosimy usilną prośbę do Prześwietnego Konsystorza, aby raczył zniewolić ks. prob. Nejczyka 1) ażeby nabożeństwa majowe odprawiał cały miesiąc, a nie tylko 3 razy w tygodniu; 2) ażeby powrócił nam nabożeństwa październikowe (różaniec) wieczorem; 3) ażeby do chorych każdy dzień przychodził z wiatykiem, a nie, jak dotąd, tylko we wtorki i piątki, i to z ambony ogłosił; 4) ażeby ceremonie 
sprawa budowy Domu Katolickiego. Z toku dyskusji wynika, że opinia publiczna niewiele wie o działalności komitetu budowy. Aby tę kwestię zbadać i budowę przyspieszyć, powołano nowy komitet, liczący jedenaście osób. W jego skład wchodził także Tadeusz Staniewski. Działalność nowego komitetu i jego odezwy na łamach prasy $^{74}$ pobudziły do aktywności poprzedni komitet z ks. Nejczykiem na czele. Swoje stanowisko ogłosił on na łamach "Gońca Wielkopolskiego" z 18 lutego 1914 r. Osoby, które go krytykowały, miał ks. Nejczyk nazwać - za pośrednictwem korespondenta "Gońca Wielkopolskiego" - „samozwańcami” i „hienami wyborczymi”.

Komitet, któremu przewodniczył Tadeusz Staniewski, w piśmie do „Postępu" z 10 marca 1914 r. podkreśla, że jego główną troską jest zachowanie polskiego charakteru projektowanej inwestycji. Ich niechęć powierzenia Domu wyłącznej władzy proboszcza nie wynika z chęci skompromitowania osoby ks. Nejczyka, lecz z troski o przyszłość. „A czy w przyszłości nie może przybyć ksiądz Niemiec do parafii swarzędzkiej?" Stąd apel do osób, które chciałyby wesprzeć finansowo mieszkańców Swarzędza, aby swe ofiary przesyłały na ręce ,jedynego prawowitego komitetu" ${ }^{\prime 75}$. Na szczęście już po paru dniach, 15 marca 1914 r., oba komitety doszły do porozumienia ${ }^{76}$. Powstał wspólny komitet, liczący 25 osób, pod przewodnictwem proboszcza. Tadeusz Staniewski pozostał członkiem tego komitetu ${ }^{77}$. W gazetach wielkopolskich ukazały się odezwy, podkreślające sukces swarzędzan i proszące o wsparcie ich zamierzenia. „Podobnie jak kosiarze z dwóch stron przeciwnych kładą pełne zboża, aby zejść się po dokonanej ciężkiej pracy, tak obywatelstwo w Swarzędzu [...] zeszło się razem teraz, połączyło się w jeden komitet, aby

ślubu i pogrzebowe na żądanie interesowanych odprawiał; 5) ażeby dzieciom naszym udzielał religii św. w budynku szkolnym, a nie w kościele, gdzie podczas ciężkich mrozów i strasznych słot dzieci marzną i się zaziębiają. Zważywszy powyższe nasze żale i bóle, a nie mając żadnej nadziei polepszenia smutnych stosunków w parafii, wyrażamy ks. prob. Nejczykowi wotum niezaufania".

${ }^{74}$ Na przykład „Postęp” 1914, nr 24, s. 3.

${ }^{75}$ W sprawie Domu polsko-katolickiego w Swarzędzu, „Postęp” 1914, nr 56, s. 1.

${ }^{76}$ Zgoda w Swarzędzu, „Postęp" 1914, nr 63, s. 2-3.

77 Niestety, powstanie wspólnego komitetu nie oznaczało końca konfliktów w parafii. Tadeusz Staniewski nadal wymieniał pisma z instytucjami kościelnymi na następujące tematy: niestarannego prowadzenia ksiąg, fałszowania dokumentów, narażania parafii na zbędne i prywatne wydatki oraz lekceważenia obowiązków duszpasterskich przez ks. proboszcza, co doprowadziło w końcu do prośby z 25 maja 1914 r. "do najjaśniejszego konsystorza o złożenie z probostwa parafii swarzędzkiej ks. Nejczyka". Ks. Nejczyk konsekwentnie przez lata odrzucał stawiane mu zarzuty, swoich oponentów nazywał „kliką”, a Tadeusza Staniewskiego „gorszycielem”: „Jak ma ta religijność zakwitnąć, kiedy właśnie autor tego pisma, Staniewski, w swoim domu utrzymuje 5 nierządnic, dziewczyn publicznych" (AAP, list T. Nejczyka do biskupa Likowskiego z 12 maja 1914 r.). 
jak najszybciej urzeczywistnić raz powzięte zadanie: wystawienie gmachu własnego"78.

Wybuch wojny położył kres zbieraniu składek. Ostatecznie dopiero w 1938 r. proboszcz Koźlik zakupił nieruchomość nad jeziorem po domu zdrojowym Marco dla Akcji Katolickiej.

W latach 1934-1935 w Swarzędzu ukazywało się pierwsze lokalne czasopismo - "Głos Swarzędza". Na jego łamach można znaleźć najstarszą i najbardziej dokładną relację z przebiegu wydarzeń w Swarzędzu w latach 19181919. Jest to anonimowy tekst pt. Pierwsze dni powstania $1918 r .{ }^{79} \mathrm{~W}$ swoich wspomnieniach autor wiele miejsca poświęcił Tadeuszowi Staniewskiemu: „Rada [Robotników] pracowała już w myśli nad przygotowaniem powstania, oczywiście w ścisłej tajemnicy wobec ówczesnej władzy niemieckiej. Dnia 28 XII 1918 rozwiązano Radę Robotniczą, a stworzono Radę Ludową i to w lokalu p. Staniewskiego, gdzie odbywały się wszelkie tajemnicze zebrania i posiedzenia. Od dnia tego odpowiedzialność i kierownictwo nad radą i siłą zbrojną wojsk polskich złożono na ręce p. Staniewskiego [...]. Późnym wieczorem dnia tego odbyło się tajne zebranie, na którem uchwalono obsadzić miasto powstańcami, mianowicie dworzec, zakłady miejskie, pocztę itp. Od tej chwili władza polska objęła w posiadanie całe miasto. Następnego dnia rano 29 XII 1918 przybył p. Staniewski w towarzystwie dwóch zbrojnych powstańców polskich do ówczesnego burmistrza p. Glabisza na ratusz i oznajmił, że podlega władzy polskiej, ponieważ rada robotniczo-żołnierska została zniesiona. Krótko potem nadesłano p. Staniewskiemu znamienny dokument, list $\mathrm{z}$ tut. żandarmerji pruskiej, zatytułowany do prezydenta republiki swarzędzkiej, donosząc jej o poddaniu się władzy polskiej"80.

Choć Swarzędz wkroczył w nową epokę, w czas budowania odrodzonego państwa polskiego, w sposób niezwykle sprawny, następnie doświadczył wielu trudności, zwłaszcza w zakresie funkcjonowania samorządu miejskiego $^{81}$. Sytuacja uległa poprawie dopiero w 1929, kiedy postanowiono wybrać na urząd burmistrza Tadeusza Staniewskiego. Zygmunt Kaczmarek uznaje ten wybór za „niezwykle trafny”. „Staniewski znając miejscowe stosunki

78 Odezwa w sprawie budowy Domu Katolickiego w Swarzędzu. „Postęp” 1914, nr 78, s. 2.

79 Pierwsze dni powstania 1918 r. "Głos Swarzędza” 1934, nr 32, s. 2; 1935, nr 1, s. 1-2; 1935, nr 2, s. 1-2; nr 4, s. 1-2. Być może autorem tej relacji jest Teofil Hoffmann, który we wcześniejszych numerach tego czasopisma opublikował cykl felietonów pt. Z historji miasta Swarzędza.

80 Pierwsze dni powstania 1918 r., "Głos Swarzędza” 1935, nr 1, s. 1-2.

81 Jak piszą badacze zajmujący się dziejami Swarzędza, w historii miasta w okresie dwudziestolecia międzywojennego zwraca uwagę fakt, że w pierwszych latach niepodległości w Swarzędzu zachodziły częste zmiany na stanowisku burmistrza. Szczególnie trudne były lata 1925-1926, kiedy ciągłe spory pomiędzy magistratem a Radą Miasta uniemożliwiły prawidłowe funkcjonowanie obu władz (W. Białek, Swarzędz 1638-1988, dz. cyt., s. 96; Z. Kaczmarek, W Polsce odrodzonej, [w:] Dzieje Swarzędza: monografia, dz. cyt., s. 127-128). 
potrafił znaleźć wspólny język z różnymi grupami społecznymi [...], okazał się człowiekiem kompromisu i mimo że w latach trzydziestych zaostrzyły się sprawy polityczne (głównie między endecją a sanacją) umiał godzić zwaśnione strony" 82 . Władysław Białek podkreśla, że „dziesięcioletni okres sprawowania urzędu burmistrza przez Tadeusza Staniewskiego stał się zarazem okresem bujnego rozwoju miasta. Burmistrz zyskał sobie sympatię i autorytet zarówno członków Rady Miejskiej, jak i całej społeczności swarzędzkiej"83. Kiedy na początku XX w. Tadeusz Staniewski przybył do małego miasteczka, jako absolwent gimnazjum wyróżniał się w otoczeniu wykształceniem. Z czasem zyskał uznanie jako kupiec i człowiek oddany aktywności obywatelskiej. Pierwsze lekcje działalności politycznej odebrał jeszcze pod zaborem pruskim, a kiedy w 1939 r. został aresztowany przez Niemców, trafił do Fortu VII nie tylko jako burmistrz, ale także jako weteran powstania wielkopolskiego ${ }^{84}$ i znany społecznik.

\section{Bibliografia}

\section{Źródła archiwalne}

Archiwum Państwowe w Poznaniu

Akta miasta Poznania, Zespół 53/474, Seria 19.3 Kartoteka ewidencji ludności 1870-1931 Jednostka 15075

Akta miasta Swarzędz, Zespół 53/4389

Jednostki:

45 Personalien der Magistratsmitglieder und Stadtverordneten

57 Bewerbungen in die Bürgermeisterstelle

219 Nachsuchung und Konzessionen und obernahme von Agenturen

313 Miejska Kasa Oszczędności

Gimnazjum im. Fryderyka Wilhelma w Poznaniu, Zespół 53/1284,

Jednostki:

43 Album des Königl. Friedrich Wilhelm Gymnasium zu Posen

223 Zensurenbogen der 1894-1895 Abgegangenen

Urząd Stanu Cywilnego Poznań, Zespół 53/1926,

Jednostki:

97 Akta zgonów

157 Akta zgonów

356 Księga małżeństw za 1898

82 Z. Kaczmarek, dz. cyt, s. 132.

${ }^{83}$ W. Białek, Swarzędz 1638-1988, dz. cyt., s. 98.

${ }^{84}$ Tadeusz Staniewski w 1934 roku został członkiem Związku Weteranów Powstań Narodowych Rzeczypospolitej Polskiej - koło Swarzędz (APP, Ewidencja członków Związku Weteranów Powstań Narodowych Rzeczypospolitej Polskiej, Jednostka 53/884/0/1/44). 
Urząd Stanu Cywilnego Swarzędz, Zespół 53/1955,

Jednostki:

101 Księga aktów narodzenia

139 Księga aktów zejścia

222 Księga aktów zejścia

Związek Powstańców Wielkopolskich w Poznaniu, Zespół: 53/ 884, jednostka 44 Ewidencja członków Związku Weteranów Powstań Narodowych Rzeczypospolitej Polskiej

Archiwum Archidiecezjalne w Poznaniu, Zespół: Konsystorz i Kuria Arcybiskupia, jednostka

KA 789 Akta personalne ks. Nejczyka

\section{Księgi adresowe}

Adress- und Geschäfts-Handbuch der Stadt Posen, Posen 1879-1897.

Adressbuch der Provinzial-Hauptstadt Posen, Posen 1900-1905.

Adressbuch der Stadt Posen sowie der Vororte Bartholdshof, Jersitz, St. Lazarus und Wilda, Posen 1898.

Fiedler Leon Karol, Przemyst Wielkopolski, Poznań 1923.

Książka Adresowa Handlu i Przemystu Polskiego w obrębie niemieckiego państwa..., Berlin 1896.

Ksiegga adresowa Polski (wraz z w. m. Gdańskiem) dla handlu, przemystu, rzemiost i rolnictwa, Warszawa 1928.

Ksiegga adresowa Polski (wraz z w.m. Gdańskiem) dla handlu, przemystu, rzemiost i rolnictwa, Warszawa 1930.

Księga Adresowa Polski (wraz z w. m. Gdańskiem) dla handlu, rzemiost i rolnictwa, Warszawa 1926.

Księga adresowa przemystu, handlu i rzemiosta zachodniej Polski, Poznań 1925.

Księga kupiectwa i przemystu polskiego w Wielkim Księstwie Poznańskiem, Poznań 1908.

Ziemkowski J., Skorowidz polskiego przemystu i handlu hurtownego, Gniezno 1912.

\section{Opracowania}

Bartoszek A., Ksiądz Tomasz Nejczyk (1865-1918) - proboszcz swarzędzki, „Zeszyty Swarzędzkie” 2011, t. 3, s. 88-103.

Białek W., Swarzędz 1638-1988, Swarzędz 1988.

Białobłocki A., Absolwenci Gimnazjum i Liceum Świętej Marii Magdaleny w Poznaniu: 1805-1950, Poznań 1995.

Dzieje Swarzędza: monografia (1638-1988), red. S. Nawrocki, Poznań 1988.

Gucia D., Stypendyści Towarzystwa Naukowej Pomocy im. Karola Marcinkowskiego 1841-1909, Mnichowo-Poznań 2017.

Kopeć S., Od Barcikowskich i Czepczyńskich do PZZ „Herbapol” S.A. w Poznaniu: wycinek z dziejów przemystu drogeryjno-zielarskiego i farmaceutycznego w Poznaniu w XIX i XX wieku, Poznań 2003.

Łączkowski A., Antoni Stanisław Jurasz 1847-1923, Warszawa 1987.

Pamiętnik Zjazdu Abituryentów Gimnazyum ad st. Mariam Magdalenam z r. 1869, Poznań 1895.

Powstanie Wielkopolskie: mieszkańcy Swarzędza w zwycięskim zrywie niepodległościowym 1918-1919, Swarzędz 2007.

Tadeusz Staniewski 1873-1940, Swarzędz 2010; wersja online: http://swarzedz.pbp.poznan. pl/files/Staniewski.pdf (dostęp 17 marca 2018 r.). [Zawiera m.in.: A. Szafran-Bartoszek, Biografia Tadeusza Staniewskiego, s. 11-12; A. Małyszka, Zmiana granic Swarzędza w czasach sprawowania urzędu burmistrza przez Tadeusza Staniewskiego (1934 rok), s. 25-33; W. Buczyński, Tadeusz Staniewski jako organizator i działacz społeczny, na przykładzie ochrony przeciwpożarowej Swarzędza, s. 34-38].

Udział mieszkańców Swarzędza i okolic w Powstaniu Wielkopolskim 1918-1919, Poznań 2015. 
Wojciechowska M., Materiaty do dziejów katolickich towarzystw robotników polskich w Wielkopolsce, „Poznańskie Studia Teologiczne” 1986, t. VI, s. 399-422.

\title{
Materiały prasowe:
}

Dr. B., Krótki zarys historyczny wsi i miasta Swarzędz, „Praca” 1901, nr 41, s. 1115.

Korespondecya. Swarzędz 28 lutego, "Postęp" z 3 marca 1909 r., s. 1-2.

Odezwa w sprawie budowy Domu Katolickiego w Swarzędzu, „Postęp” 1914, nr 78, s. 2.

Opłakane stosunki w parafii swarzędzkiej, „Orędownik” 1913, nr 220, s. 2.

Oświadczenie [Towarzystwa Robotników], „Postęp” 1909, nr 279, s. 1-2.

Pierwsze dni powstania 1918 r., "Głos Swarzędza” 1934, nr 32, s. 2; 1935, nr 1, s. 1-2; 1935, nr 2, s. 1-2; nr 4, s. 1-2.

Spis Katolickich Towarzystw Robotników Polskich należących do Zwiąku diecezjalnego archidiecezji gnieźnieńskiej i poznańskiej. Dodatek do: „Robotnik” z 4 marca 1906 r.

Szafran A. M., Tadeusz Staniewski (1873-1940), delegat Swarzędza na Polski Sejm Dzielnicowy, „Przegląd Wielkopolski” 2007, nr 2, s. 33-36.

Szałek M., Tadeusz Staniewski: pierwszy burmistrz Swarzędza w odrodzonej Polsce , „Prosto z Ratusza” 2007, nr 10, s. 10-11.

W sprawie Domu polsko-katolickiego w Swarzędzu, „Postęp” 1914, nr 56, s. 1.

W sprawie wyborów do rady miejskiej w Swarzędzu, "Orędownik” 1909, nr 293, s. 3.

Wyborca, W sprawie wyborów swarzędzkich. „Postęp" 1909, nr 273, s. 2.

Zgoda w Swarzędzu, „Postęp” 1914, nr 63, s. 2-3.

\section{Barbara Ksit}

\section{Działalność publiczna Tadeusza Staniewskiego w Swarzędzu do roku 1918}

\begin{abstract}
Streszczenie
W 1919 r. Tadeusz Staniewski jako pierwszy Polak objął stanowisko burmistrza w podpoznańskim mieście Swarzędz. Funkcję tę pełnił społecznie przez dziewięć miesięcy. Ponownie wybrany burmistrzem w 1929 r., pełnił tę funkcję do 1939 r. Dotychczasowe opracowania omawiają działalność Tadeusza Staniewskiego w Swarzędzu, począwszy od listopada 1918 r. Niniejszy artykuł ma być próbą poszerzenia wiadomości na jego temat we wcześniejszym okresie. Syn nauczyciela, ukończył Gimnazjum Fryderyka Wilhelma w Poznaniu. Na początku XX w. osiadł w Swarzędzu, gdzie zyskał uznanie jako kupiec i społecznik. W odniesieniu do lat 1900-1918, kiedy Tadeusz Staniewski stawiał pierwsze kroki w działalności publicznej, najlepszym źródłem jest prasa wielkopolska, zwłaszcza "Postęp” i „Orędownik” - czasopisma reprezentujące interesy drobnomieszczaństwa. Działalność Tadeusza Staniewskiego była omawiana na ich łamach szczególnie w kontekście dwóch wydarzeń istotnych dla Polaków w Swarzędzu - wyborów do Rady Miejskiej w 1909 r. i sprawy budowy Domu Katolickiego.
\end{abstract}

Słowa kluczowe: Staniewski Tadeusz, Swarzędz 


\title{
Public activity of Tadeusz Staniewski in Swarzędz until the year 1918
}

\begin{abstract}
In 1919, Tadeusz Staniewski was the first Pole to become mayor of Swarzędz, a town just outside of Poznan. He held this position for 9 months with no remuneration. He was re-elected in 1929 and remained the mayor of Swarzędz until 1939. Previous articles on the activity of Tadeusz Staniewski in Swarzędz discuss his life from November 1918. The present article aims at expanding this timespan and includes information about him in earlier periods. Son of a teacher, he graduated from Frederick William College in Poznań. In the early $20^{\text {th }}$ century he settled down in Swarzędz, where he gained recognition as a tradesman and social activist. Regarding the years 1900-1918, when Tadeusz Staniewski entered the public sphere, the best sources are press articles published in Greater Poland journals, especially "Postęp" and "Orędownik" which represented the interests of the lower middle class. The activity of Tadeusz Staniewski was discussed there particularly with regard to two events of major importance for Poles in Swarzędz: the 1909 City Council elections and the construction of the Catholic House.
\end{abstract}

Key words: Staniewski Tadeusz, Swarzędz 